\section{(D) http://orcid.org/0000-0002-4695-0488 \\ University of Warmia and Mazury in Olsztyn, Poland e-mail: agnieszka.jaszczak@uwm.edu.pl \\ http://orcid.org/0000-0001-5769-7441 \\ Joanna Żukowska \\ Gdańsk University of Technology, Poland e-mail: joanna.zukowska@pg.edu.pl}

(D) http://orcid.org/0000-0003-4164-8180

Beata Dreksler

American University of Beirut, Lebanon e-mail: bd08@aub.edu.lb

http://orcid.org/0000-0003-0163-5940

Nayla Al Akl

American University of Beirut, Lebanon e-mail: na143@aub.edu.lb

\title{
PLANNING OF THE GREEN ROAD SYSTEM AS AN ELEMENT OF SPATIAL MANAGEMENT IN SUBURBS AND SMALL TOWNS
}

\begin{abstract}
The premise for the development of sustainable forms of road infrastructure in small towns is the appropriate plan at an early stage or modification in the case of existing spaces. A multidirectional approach is extremely important, which takes into account the specificity of the regional (country) road system, availability, and capacity of traffic network, but also social and environmental factors. Efficient management of transit space in small cities through the implementation of the concept of managing green areas in traffic zones allows improving safety and quality of residents life. Therefore it is important to develop comprehensive projects covering
\end{abstract}


not only the project itself but also its implementation through the proper control of movement of vehicles, bicycles, and pedestrians, using e.g. traffic calming elements. The aim of this study is to enhance the design of traffic calming measures by using principles of zoning, public space design and planting strategies. Examples of development of traffic calming measures in small towns and suburban zones in the regions of Europe and MENA are presented and recommendations regarding the planning of roadside space and the introduction of plants to the traffic calming measures are formulated.

Keywords: traffic calming zones, spatial management, small towns, greenery

\section{Streszczenie}

\section{Planowanie zielonego systemu drogowego, jako element zarządzania przestrzenią w strefach podmiejskich i małych miastach}

Założeniem rozwoju zrównoważonych form infrastruktury drogowej w małych miastach jest odpowiednie jej planowanie na wczesnym etapie lub modyfikacja już istniejącej. Wielokierunkowe podejście jest niezwykle ważne nie tylko ze względu na specyfikę regionalnego (krajowego) systemu dróg oraz dostępność i przepustowość ruchu, ale także czynniki społeczne i środowiskowe. Sprawne zarządzanie przestrzenią w małych miastach poprzez realizację koncepcji zarządzania terenami zielonymi w strefach ruchu pozwala na poprawę bezpieczeństwa i jakości życia mieszkańców. Dlatego istotne jest, aby opracowywać kompleksowe programy obejmujące zarówno sam projekt, jak też jego wdrożenie poprzez właściwą kontrolę ruchu pojazdów, rowerów i pieszego za pomocą tzw. elementów uspokajających ruch. Celem tego badania jest analiza zastosowania środków uspokojenia ruchu w planowaniu przestrzeni komunikacyjnych. Dlatego też w pracy nawiązano do koncepcji planowania infrastruktury drogowej opartej na zasadach strefowania i wspólnych przestrzeni, a także wykorzystania form roślinnych i małej architektury jako materiału do projektowania stref ruchu. Docelowo przedstawiono przykłady rozwoju małych miast i stref podmiejskich w regionach Europy i MENA. Artykuł porusza także inne kwestie, w tym problemy społeczne i wpływ ograniczeń ruchu na użytkowników dróg.

Słowa kluczowe: strefy uspokojonego ruchu, zarządzanie przestrzenią, małe miasta, zieleń

\section{Introduction}

Rapid industrialization, development of technologies, increasing population and the resulting urbanization has resulted in an unprecedented increase in vehicles in the traffic all over the world. Nowadays, these factors are not only underlined in big cities, but they are also a big challenge for the midsized or small towns. Such increasing urbanization, united with the rise in a number of vehicle possession, has led in recent years to an increased demand of traffic planning for both long term and short term period. Furthermore, the increasing traffic in the suburbs and small towns causes higher danger on the road.

Traffic calming is not a new idea. The first measure was introduced with the 1865 Red Flag Act in the UK, that restricted vehicle speeds to about $4 \mathrm{mph}$, by requiring a pedestrian to walk in the front of the moving vehicle. After its repeal in 
1896 road vehicles developed rapidly [Cebon, 1993; Department of Transport..., 2007]. Currently, a larger number of road users with existing access to road infrastructure requires the roads quality improving and the planning of traffic calming elements as well as green infrastructure. Increasingly, the authorities aim to change drivers' attitudes and perception of the appropriate speed. It includes physical changes to the streetscape, driver education, and awareness as well as development of the appropriate schemes for the area [Department of Transport..., 2007].

A larger number of road users with existing access to road infrastructure requires the roads quality landscape improvements to be holistic, looking at road safety, road experience and environmental impact and therefore planning of traffic calming elements as well as green infrastructure. A larger number of cars also means the need for proper organization of parking spaces and parking lots. Another problem is the lack of small areas of green space adjacent to the road, meaning that the culturaly relevant experience of rural landscapes along the roads is being lost. The issues of introducing greenery into the road surroundings are important not only from the point of view of ecology or aesthetics but are also directly related to road safety. By the proper design of the traffic calming zones, including plant forms within them, it is possible to control the car, bicycle, and pedestrian traffic in a sustainable way. The problem of traffic calming and planning safe transport systems in small towns and suburban zones is particularly important not only in the Europe regions, but also for the MENA regions, including countries like Lebanon and Jordan, where awareness of such issues is growing. Previous transport planning solutions in these countries resulted from their local specificity. However, it is important to look for new directions and possibilities to introduce changes to the road space, so as to stop the number of accidents.

The aim of the study is a comparative analysis of the use of traffic calming measures for the road safety in the road infrastructure in the selected regions, with particular reference to applications of greenery and to its applications in the small towns. While these issues have generally been addressed in regions or countries that have had long experience in the planning and shaping of communication zones with formal and highly regulated solutions, it is beneficial to investigate how these issues are raised in different conditions and areas of the world, including ones with different spacial, social, cultural as well as a variety of formal and informal planning contexts. Therefore, the article investigates proposals in well-developed regions in application of green infrastructure in traffic calming measures (Dutch and German examples), and presents examples of cases in countries currently in the full process of developing planning systems for green transportation zones (Polish and Slovak examples), as well as ones in which the transportation zone planning system is in its early stages (Lebanon and Jordan). The latter is particularly important in highlighting informal solutions that may not have been consciously planned, and for this reason will remain secondary in providing technical aspects of the approach. The study used the following methods:

- analysis of monographic and cartographic materials, plans and planning records, and other documents, 
- spatial and landscape analysis by authors based on observation,

- analysis of green communication system planning in selected countries.

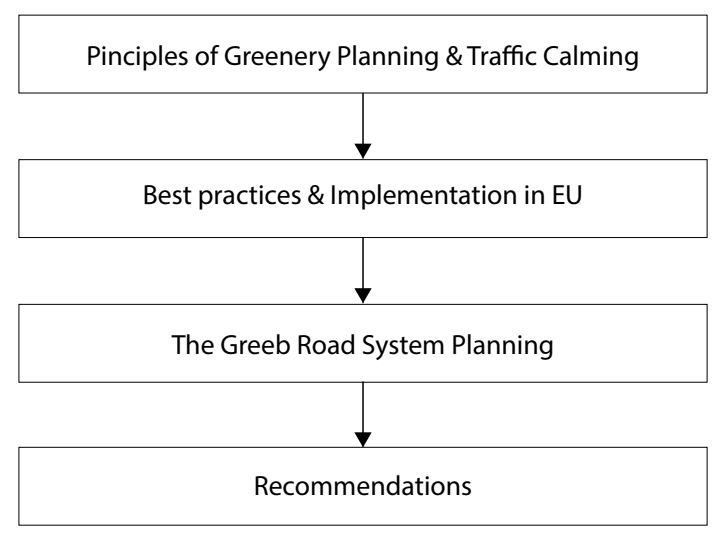

Fig. 1. Scheme of methodology

Source: own elaboration.

\section{Spatial management and transport planning in the context of road safety}

According to Sipes and Sipes [2013], transportation planning is closely linked to land use planning and is important for implementation of land use policies which can help communities and regions balance the demands of growth with the health of environmental resources. Land use planning and zoning practices, involving the layout of roadways, have a significant impact on urban development patterns and the physical layout of communities [Stipes, Stipes, 2013]. Traffic congestion and parking difficulties are one of the most prevalent transport problems in large urban agglomerations, in small towns or suburbs and residential areas the speed of the traffic is often a problem and restrictions need to be used to control speeds, vehicle class or volume of traffic. Through consistent speed management, the road safety could be significantly improved, as well as traffic noise and air pollution improved [Budzyński et al., 2017].

Traffic calming include organizational, design and legal activities; the aim is to reduce the negative impact of car traffic on the environment, modify drivers' behavior and improve the conditions for non-motorized road users by applying appropriate engineering measures. The immediate purpose of traffic calming is to reduce drivers' speeds where speeds are excessive or inappropriate for the type and use of the road. The justification for applying appropriate measures is usually based on improving safety by reducing accidents. According to Taylor and Tight [1996] by reducing speed by $15 \mathrm{~km} / \mathrm{h}$ personal injury accident might be reduced 
by $60-70 \%$ [Taylor, Tight, 1996]. Also, the proportion of accidents that are fatal or involve serious injury is reduced [Webster et al., 2005].

This activity should be conducted according to the principle of concessions and compromises, respecting and reconciling interests in such a way that the proposed solutions are acceptable to all interested parties, often representing conflicting interests, i.e. residents, local authorities, road users, etc., and as a result, reconciling the layout requirements with the local transport needs. Traffic calming schemes are an important element in local road safety strategies, which set out how authorities plan to tackle road traffic casualties in their area. Implementation of traffic calming can be reduced to applying a single measure as well as a comprehensive urban and transport concept aimed at improving the condition and functioning of the urban environment. Nowadays traffic calming goes beyond safety benefits and includes: reduction of noise, vibration, and air pollution, as well as rise of neighborhood pride and attract private investment [Reid, 1999]. Higher effectiveness is characterized by comprehensive solutions, involving various means of traffic calming and involving accompanying activities of an educational, propaganda and preventive nature. Traffic calming should not be limited to speed reduction only for individual streets and small areas. The goal is to improve road, construction and ecological conditions in city districts, including collective streets and taking into account different types of transport. By implementing solutions for traffic calming, one can achieve goals related to road safety improvement, as well as the arrangement of traffic areas, improvement of the urban landscape, environmental conditions, and facilitation of internal communication.

Environmental impact can cover air quality, visual and landscape quality, cultural heritage, flora and fauna, drainage, social cohesion, impacts on the economy and overall quality of life. In visual preference surveys, scenes containing landscaping and other natural elements tend to be rated highest. Landscaping elements enhance appearance and might improve the effectiveness and safety of the circles by drawing attention to them. They create distinctive and pleasing streetscapes where vertical element - trees, shrubs, planters - should draw attention [Wallen, 1961].

\section{Traffic calming in small towns, suburbs and residential areas}

Road network means accessibility, but at the same time it provokes negative effect on local inhabitants, flora, and fauna. Roads create physical barriers such as the increased resistance of movement, disturbance along the road and traffic casualties due to collisions during crossings [Fluit et al., 1990]. These barriers create fragmentation of the landscape [Jaarsma, Willem , 2002], that applies also to residential landscapes, its inhabitants and their social life. In small communities, roads are used by pedestrians, cycles, and different vehicles. This produces inconsistency between the mobility of different users. Generally, drivers do not adequately reduce speeds while crossing small urban or residential areas [Galante 
et al., 2010] that calls for traffic calming measures. With traffic calming, the street becomes an extension of the neighborhood - a place to walk, chat, socialize and play [Cervero et al., 2017]. In small towns, suburbs and residential areas there are 3 types of roads that are suitable for traffic calming [City of Toronto..., 2016]:

- local roads that provide access to properties,

- collector roads that provide access to properties and traffic movement,

- minor arterial roads where the traffic is a primary function.

Major arterial roads and expressways with design speed $60-120 \mathrm{~km} / \mathrm{h}$ and volume of traffic greater than 20,000 vehicles/day are not suitable for traffic calming and generally do not allow pedestrian and cyclist access. With regard to the roads passing through small towns, or suburbs and the residential areas of cities, the specific objectives of the traffic calming are:

- general reduction of road traffic, especially heavy traffic,

- improving safety by lowering average speed and reducing differences in vehicle speed in the traffic flow,

- drawing attention to the specificity of the road environment and enforcing safe behavior,

- reducing the environmental nuisance of traffic and reducing the barrier effect between parts of the built-up area,

- increasing the requirements for means of transport (pedestrian and bicycle traffic, urban transport: buses, trams, trains, queues),

- improvement of the aesthetics and quality of life of a given residential area by introducing road free zones and increasing the area of green areas (parks, squares, etc.).

Traffic calming in small cities is possible by applying various measures that also improve the quality of life. Effective traffic calming policy requires the following aspects to be taken into account:

- traffic calming should be implemented in large part of the city or in the whole city and include also streets important for road traffic (a network of collective streets),

- road, environmental, construction and social problems requires an interdisciplinary and balanced approach to the problem. Taking into account the importance of involving residents in the development of traffic calming schemes and providing them with an understanding of what can be achieved,

- the current budget, the most financially beneficial means should be chosen and actions should be taken first and foremost in particularly conflict-related points,

- during the implementation of the project, it is necessary to obtain the approval of funds from all participants, which increases the chance of respecting accepted applications after their implementation.

The society does not always support traffic calming. However, the growing acceptance of measures aimed at counteracting road hazards in recent years is a sign of the success of the implemented projects. In order to achieve traffic calming, an extensive set of methods and measures should be used, the selection of which 
must always refer to local conditions and the area of application. In general, several urban zones can be distinguished, differing in the requirements regarding the use of traffic calming measures:

- zones with a predominance of housing functions,

- city centers and service and commercial centers,

- the environment of special-purpose facilities (schools, hospitals, recreational areas),

- collective streets (component of the urban traffic zone),

- green connectors built to improve access across the city by bicycle or on foot,

- housing estates and small towns with no clear division of the function of the area used.

The choice of traffic calming measures for each of the above zones should result from the analysis of the effectiveness of these measures in specific road, traffic and spatial conditions.

\section{Traffic calming measures - experience of different countries}

Traffic calming zones have been included in the German Road Traffic Regulations (StVO) for first time in 1980. They are marked with the road sign No. 325 and are subject to section 42, paragraph 2 of the German traffic regulations. From a practical point of view, these road signs are considered to mark the beginning and end of built-up or residential areas [Road Safety..., 2015]. In Netherlands the Sustainable Safety vision was introduced in the early $90 \mathrm{~s}$. The conscious application of shared space and the integration of traffic into social spaces was carried out by pioneers such as Joost Vahl [Hamilton-Baillie, 2008].

From 1998 the vision has been clearly visible in the road safety policy. In that year the Start-up Programme Sustainable Safety commenced. Now, considerable progress has been made with the implementation of the measures that are in accordance with the Sustainable Safety Vision [De balans opgemaakt..., 2009].

Due to Polish political situation the motorization had been developing slower than in Western European countries thus the problems of congestion, traffic safety and emissions appeared later than in Germany. Nevertheless soon after the economy had changed into the free market one, the consequences of the uncontrolled development of motorization started to be a serious problem. Esspecialy for the urban planning too high traffic with too highly speeds started to be a problematic issue. The first traffic calming measures aimed at reducing speed were introduced in the early 90 s. They quickly gained popularity, mainly due to their effectiveness and low cost. Currently, in Poland, more and more solutions are being created in the field of traffic calming. A very well known is the project "Dutch Town Pulawy", where local and transit traffic was approached with a different element of traffic calming from the Netherlands [Jamrozik et al., 2009]. 
In Slovakia, the principles of design of the elements of traffic calming for the road transport in villages and towns are set in the document adopted in 2005 [Bezák, 2005], and amended in 2006. Among other calming measures, they mention greenery as one of the important element of traffic calming. The most common treatment is the division of the road cross-section by embedding the side-traffic island, where the use of low or high greenery is recommended. By a combination of different types of greenery separation of vehicles, pedestrians and cyclists can be achieved. The use of greenery highlights and increases the calming effect, it increases the aesthetics of the street and amends the microclimate and hygiene conditions at a given location.

In Lebanon, to our knowledge, no policy currently exists for streetscape calming measures in general, beyond the conventional use of speed control, speed bumps, traffic lights and traffic regulating agents. Although the interest has been growing, so far there is no clear guide on the importance given tothe use of landscape design as a tool for designing the calming measures in particular, although discussions for the need of such measures has resulted in the ministry of agriculture looking into potential guidelines to do so. Streetscape design is mostly the outcome of zoning and building laws, mainly related to set back and to build façade requirements for urban plans. The adoption of new traffic law and efforts of the UN Decade for Road Safety in 2011, unfortunately, was still paralleled with an increase in road fatalities in the country by $12.93 \%$ between 2010 and 2014 . The ministry of agriculture (MoA) is currently working on the guidelines for "Road Landscape Design to Enhance Road Safety". It aims to develop technical guidelines to integrate road safety concepts in future road landscape design in order to improve road safety and the safety of its users [Samaha, 2015].

In Jordan, traffic safety is coordinated by Central Traffic Department, a unit of Public Security Directorate. The traffic calming measures applied by Traffic Department are traffic surveillance, traffic awareness (the usage of display monitors, education), coordination with traffic safety stakeholders (organize traffic movement and solve or reduce roads traffic and usage of modern technology [Traffic Department, 2016]. To our knowledge, there is not any planning policy that uses physical design to improve safety. The main element used in the country is roundabout, that aims to control speed as well as a traffic jam [Al-Masaeid, 1999].

\section{The function of greenery in planning green road systems and traffic calming}

Greenery in the transportation areas retains water, has a positive effect on the microclimate and purifies the air. However, greenery planted along roads and streets is exposed to biotic and abiotic environmental factors. Stressogenic abiotic factors such as air and soil drying as well as extreme temperatures have the greatest impact on the growth of vegetation. Also, the use of chemicals and mechanical measures for winter road use (especially in Central Europe) has a negative impact 
on of trees and shrubs growing in the road lane. Proper management of green areas consists in weakening the negative impact of urbanization, providing water necessary for the functioning of vegetation and reducing the costs of its maintenance [Woźny, 2015].

Trees and shrubs form a natural protective barrier against wind, reducing its strength. Depending on the width and height of the belt vegetation and its proximity to the zone it is assumed that this is from 20 to $80 \%$. Vegetation, especially trees and shrubs, reduce the temperature of the air by reflecting and absorbing sunlight through the leaves. This is especially important in the hot and arid MENA regions, where the temperature is relatively high during the spring and summer seasons. An important role, in this case, also has the increase in air humidity and soil as well as counteracting water and air-soil erosion by stopping rainwater. In the conditions of Central Europe, it is also important that the roots facilitate the slow infiltration of rainwater into the ground thereby preventing floods. The technical significance of green areas is primarily associated with noise suppression, but also with insulation and covering of space and buildings. Every year the traffic is becoming more and more onerous, which is associated with the ever-increasing levels of noise and vibration associated with it [Woźny, 2015]. Greenery in suburban areas connecting to communication is of landscape importance. Alleys or "green screens" (roadside embankments planted with vegetation or grass) create landscape sceneries and lay out the scenic routes as well as minimizes the visual impact of the road on the larger reading of the landscape, especially in mountainous terrains. All landscape elements can be divided into those occurring inside the alley (in its structure) or connecting with the environment (outside the roadway). The aesthetic values of greenery in the communication zones also include the characteristics of plants that affect the perception of the landscape in a positive way. These include, among others color of plant elements. Throughout the growing season, the trees take on a shade of green depending on the species and variety, and in the autumn they color into various hue [Jaszczak, 2008].

Streets are not only places to drive. They are spaces for people not only for cars, form an important pedestrian networks in rural areas where streets are often mixed and pedestrian and vehicular zones overlap. Mobility as the main function is combined with multi-use, spatial function. Cultural, social and environmental elements become an integral part of its aesthetic and functionality [Bain et al., 2012]. Policies and guidelines might enhance streets' safety and visual characteristics. Therefore context-sensitive solutions and standards are crucial for mobility and identity of the local community.

Planning greenery in road's network is an extremely important task. Meanwhile, this topic is undervalued in many regions. It happens that the introduced greenery is limited to lawns or plantings introduced contrary to the principles of proper planning (from the technical and utility point of view). However, in many European countries guidelines for the establishment of greenery on roads in transportation routes (car, bicycle, and pedestrian), intersections or traffic calming zones have been introduced. The projects assume multifunctional use of such spaces, by applying the rules of combined traffic (e.g., in the Netherlands or Germany). In 
Poland or Slovakia, we are dealing with the improvement of the management of transportation zones with regard to plant forms; however, in this case, greenery is most often adapted to existing transportation systems, which causes some limitations in the implementation of the principle of traffic calming. Problems occur especially in central built-up areas and where the road system has remained unchanged since the post-war years, especially in the $60 \mathrm{~s}$ and $80 \mathrm{~s}$ of the $20^{\text {th }}$ century, where there was a system of car traffic separation from a pedestrian. As a result, there is a lack of space for greenery, for example in the lanes of walking and cycling paths. It is very difficult to describe unified urbanization trends in Europe and MENA region because of a great diversity of socio-economic, human and natural resources characteristics as well as approaches to the topic. Therefore, planning green areas associated with the road network is not a mandatory action, and often results from completely different needs than transport itself (e.g. greenery of symbolic or cultural significance). In Lebanon very rarely traffic calming measures are introduced by authorities; usually, they are remains of important elements of the social, cultural or religious identity. While formal road landscape design to enhance safety is relatively in existant, we can still witness informal ways by road landscapes have influenced road behavior and acted as calming measures within the local context of small Lebanese towns. Elements such, i.e. an old oak or olive trees were important enough for the local community to build the road around them instead of moving them somewhere else. Very often roundabouts are constructed around a central cultural or political feature and serve as calming measures. Lane narrowings happen very often because of private possessions and grey zones created by overlapping properties.

The growing number of road users has led to traffic collisions becoming more frequent. Plants planted along the streets in accordance with technical rules contribute to the improvement of safety. Shading the driving path (important for high sunlight) promote better visibility of oncoming vehicles from the opposite side. This also applies to other road users. Insertion of belt greenery between the road and the pavement and the so-called "island" protects against the unexpected intrusion of pedestrians. The most common barrier is, in this case, hedges, thorn plants or creeping bushes and perennials. In turn, the compact and elastic structure of plant offshoot in the roadside green belt can prevent the tragic consequences of accidents. Homogeneous planting protects drivers' psyche from an excess of impulse related to advertising, infrastructure, etc. In contrast, groups of plants distinguished by color interrupt the monotony of the surroundings and enhance concentration.

Greenery, trees, and shrubs, must not interfere with the communication corridor and shall not impede the view and mutual visual contacts of drivers, pedestrians, and cyclists. The greenery shall not cover the vertical traffic signs and shall not worsen the conditions for the illumination of the calming element and the surrounding area. Particular attention must be paid to the seasonal mobile greenery and regular care of the existing greenery throughout the year. The increased requirements of care are often the main constraint of the greater use of green vegetation elements [Kristiánová, Marcinková, 2015]. 
The used traffic calming measures, taking into account the forms of the plants, can be divided into three categories: the deflection of the road, road narrowings, and the central island. They can be made in various technologies and using various materials. However, in order to achieve the synergy effect described above, taking into account both the improvement of the safety of residents and landscape aesthetics, it is desirable to introduce greenery not only as a supplementary element but also to strengthen engineering solutions (FRIL, 2005). In many cases, greenery itself can also be an engineering measure reducing speed, especially in suburban zones (e.g., as an entrance gate to the city, or avenue along the roadway). The best way to take into account the safety rules is to signal the driver to change the speed through vertical accents (e.g., trees of appropriate sizes) underlain with low cut shrubs. Among the green areas used in suburban communication zones and small towns, we can distinguish:

- road verge (usually as a lawn, planting shrubs, low ornamental vegetation),

- "green screens" - slopes and tunnels planted with vegetation,

- avenues, one-sided or double-sided tree plantings,

- "entry gates" to the city (usually as high vegetation),

- greenery at intersections (roundabouts),

- greenery at median strips,

- green on the road extension,

- greenery in the lanes separating walking and cycling paths,

- traffic islands / median island,

- chicanes.
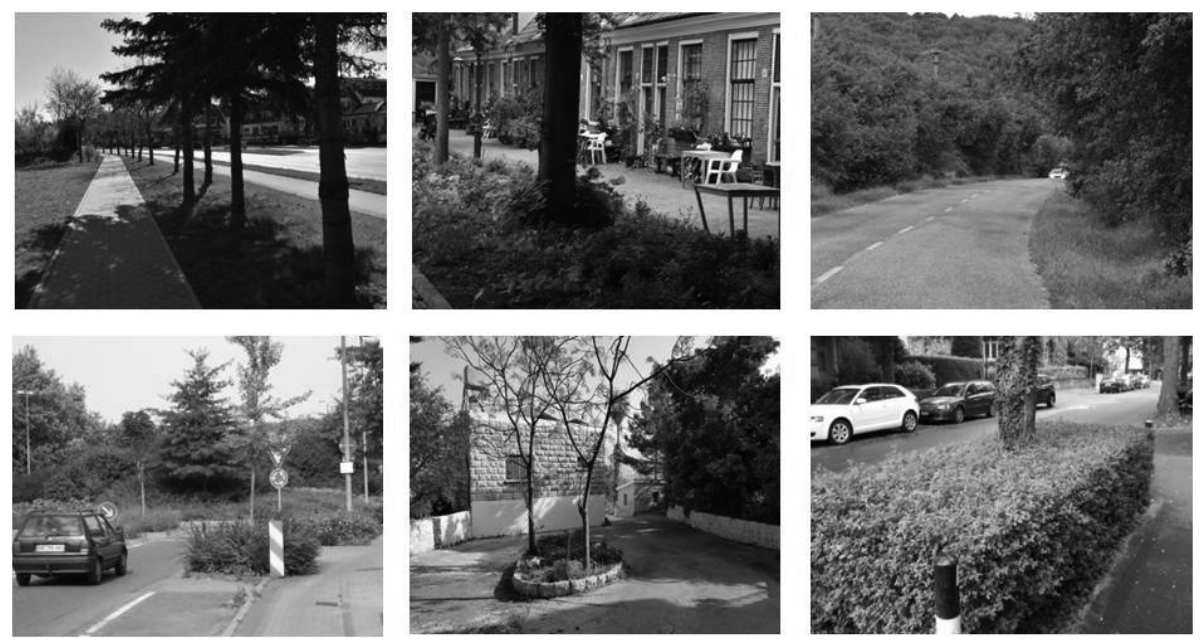

Fig. 2. Examples of greenery in roadside zones in selected countries Poland, Netherlands, Slovakia, Germany, Lebanon (line trees, shrubs belts, green roundabouts, green parking spaces) Source: own elaboration. 


\section{Greenery in traffic calming - experience of examined countries}

In Germany and the Netherlands for example, planning greenery in the zones of calmed traffic takes place in a comprehensive manner. Thus, vegetation planned in accordance with the principles of establishing these forms of greenery as well as road safety is used in all elements of the traffic calming.

In Poland and Slovakia, the most often planned elements of traffic calming in small towns (including greenery) are roadside pedestrian refuges, road verges, successively roundabouts and islands, followed by narrowing and expansion. The implementation of the traffic regulations and calming measures may have contributed significantly to the observed decrease in mortality rates of road users in the Slovak Republic in the period 1996-2014 [Brazinova, Majdan, 2016]. A significant decrease in mortality was observed in all population groups and in all groups of road users. Roundabouts have become the most common traffic calming element implemented in the small cities in Poland and Slovakia. The municipalities are satisfied with the safety and flow of the traffic, however in some cases the continuous flow of the traffic is hindered by roundabouts. The roundabouts became elements of the art-design, often situated at the entrance points to the cities. They are designed as welcoming points, they are planted thematically, or seasonally, or are often decorated by sculptures.

In Lebanon and in Jordan many of "informal" traffic calming measures are median strips, roundabouts, engineering measures such as speed humps, lane narrowings such as chicanes and curb extensions. Sometimes they include vegetation, but it is not a rule. If vegetated they include trees and palm trees. The vegetation may vary from a mix of flowers, gropudncover, shrubs, trees or a combination of those elements. In urban areas, the reliance on street medians, roundabout and street trees is often perceived. Roundabouts located in Amman for instance include shrubs and groundcovers and are carefully maintained. They are not only traffic calming measures but also may serve as orientation points for citizens and visitors. Some of them, like Al Waha Circle in Amman, might separate roads not only horizontally but also vertically.

In towns and villages, trees, especially old, culturally or spatially significant trees are sometimes protected when roads are built and thus become remains of a previous landscape within the new road. Whenever possible, these are integrated within the infrastructural framework as a road island or delimited landscape and this a traffic directing measure. This landscaped feature serves both to safeguard the tree and to enhance the road safety. 
Table 1

Characteristics of main green spaces in transportation zones in selected regions

\begin{tabular}{|c|c|c|c|}
\hline Country & $\begin{array}{l}\text { Green verges along } \\
\text { the road, mid-road- } \\
\text { side avenues }\end{array}$ & $\begin{array}{l}\text { Roundabouts and } \\
\text { road intersections }\end{array}$ & Medians, narrowing \\
\hline Lebanon and Jordan & $\begin{array}{l}\text { Well maintained if } \\
\text { located in town's } \\
\text { centers, trained vines } \\
\text { and trellises in, stone } \\
\text { walls, streetscape } \\
\text { greenery, plant- } \\
\text { ing pattern, green } \\
\text { vergesin }\end{array}$ & $\begin{array}{l}\text { Very often include } \\
\text { icons (monuments, } \\
\text { sculptures, elements } \\
\text { important for the } \\
\text { community, vegeta- } \\
\text { tion used for beauti- } \\
\text { fication }\end{array}$ & $\begin{array}{l}\text { Often used for central } \\
\text { arterial streets, some- } \\
\text { times include pedes- } \\
\text { trian refuges. Planted } \\
\text { with palms and trees }\end{array}$ \\
\hline Other MENA region & $\begin{array}{l}\text { Vary according to the } \\
\text { country. In the Gulf } \\
\text { often well maintained, } \\
\text { especially in repre- } \\
\text { sentative areas. In } \\
\text { poorer countries very } \\
\text { often does not exist or } \\
\text { are neglected }\end{array}$ & $\begin{array}{l}\text { In the Gulf well land- } \\
\text { scaped, often with the } \\
\text { thematic approach } \\
\text { (Oman, Dubai), well } \\
\text { maintained. In other } \\
\text { countries usually with } \\
\text { vegetation (mostly } \\
\text { trees and palms) }\end{array}$ & $\begin{array}{l}\text { In the Gulf well } \\
\text { landscaped and well } \\
\text { maintained. In other } \\
\text { countries sometimes } \\
\text { with vegetation (most- } \\
\text { ly trees and palms). } \\
\text { Often do not include } \\
\text { vegetation }\end{array}$ \\
\hline Poland & $\begin{array}{l}\text { Roadside plantings } \\
\text { depending on the } \\
\text { type of road, older } \\
\text { mostly on local roads } \\
\text { from the following } \\
\text { species: lime, maple, } \\
\text { oak. Rare fruit trees. } \\
\text { Typical for regions of } \\
\text { North-Eastern Poland } \\
\text { (Warmia and Mazury, } \\
\text { Pomerania) }\end{array}$ & $\begin{array}{l}\text { Roundabouts the most } \\
\text { often planned green } \\
\text { areas. Rarely in the } \\
\text { form of a hill, often } \\
\text { flat with low vegeta- } \\
\text { tion or lawn }\end{array}$ & $\begin{array}{l}\text { Usually near pedes- } \\
\text { trian crossings in the } \\
\text { form of lawn less } \\
\text { often in the form of } \\
\text { bushes }\end{array}$ \\
\hline Slovakia & $\begin{array}{l}\text { Depending on the } \\
\text { type of the road, local } \\
\text { factors, and space } \\
\text { limitations, tree alleys } \\
\text { are used, in an urban } \\
\text { environment often } \\
\text { composed of intro- } \\
\text { duced salt-tolerant, } \\
\text { pruning, and drought } \\
\text { tolerant species }\end{array}$ & $\begin{array}{l}\text { The landscape design } \\
\text { of roundabouts often } \\
\text { reflects the specific } \\
\text { local identity of a city; } \\
\text { roundabouts include } \\
\text { monuments, works } \\
\text { of arts, they are often } \\
\text { thematically or sea- } \\
\text { sonally decoratively } \\
\text { planted }\end{array}$ & $\begin{array}{l}\text { The use of medians is } \\
\text { often limited by lack } \\
\text { of space in existing } \\
\text { built-up structures. } \\
\text { When used, they are } \\
\text { without vegetation, or } \\
\text { in some cases planted } \\
\text { by grass, low shrubs, } \\
\text { and where spatial } \\
\text { conditions allow, by } \\
\text { trees }\end{array}$ \\
\hline
\end{tabular}




\begin{tabular}{|c|c|c|c|}
\hline Germany & $\begin{array}{l}\text { Diverse species de- } \\
\text { pending on the type } \\
\text { of road, local and } \\
\text { historical factors, } \\
\text { e.g., birch avenues in } \\
\text { Lüneburger Heide, } \\
\text { oak and linden alleys } \\
\text { in Mecklenburg Vor- } \\
\text { pommern, no or small } \\
\text { number in the Ostfrie- } \\
\text { sland region }\end{array}$ & $\begin{array}{l}\text { Depending on the } \\
\text { type of intersection, } \\
\text { in the zone outside } \\
\text { the strict center - } \\
\text { a hill form with plant } \\
\text { compositions. Often } \\
\text { a decorative form of } \\
\text { greenery. In estate } \\
\text { zones, they are de- } \\
\text { signed lower due to } \\
\text { the smaller area }\end{array}$ & $\begin{array}{l}\text { Very often it occurs } \\
\text { in the form of green } \\
\text { shrubs or groups } \\
\text { forms up to the height } \\
\text { of } 1 \mathrm{~m} \text {. Decorative } \\
\text { vegetation is popular }\end{array}$ \\
\hline Netherlands & $\begin{array}{l}\text { Diverse species de- } \\
\text { pending on the type } \\
\text { of road, local environ- } \\
\text { mental factor }\end{array}$ & $\begin{array}{l}\text { Depending on the } \\
\text { type of intersection, } \\
\text { in the zone outside } \\
\text { the strict center - } \\
\text { a hill form with plant } \\
\text { compositions. In } \\
\text { estate zones, they are } \\
\text { designed lower due } \\
\text { to the smaller area. } \\
\text { Decorative bulbs are } \\
\text { used very often }\end{array}$ & $\begin{array}{l}\text { Very often green } \\
\text { island separate car } \\
\text { traffic zones from } \\
\text { cycling and walking. } \\
\text { Bicycle lanes forming } \\
\text { green along the bike } \\
\text { paths }\end{array}$ \\
\hline
\end{tabular}

Source: own elaboration.

\section{Conclusion}

Roadside space in small towns and suburbs is multifunctional, it has not only transport function, but also natural and protective (especially in places with greenery), cultural and symbolic (referring to history, tradition, religion), as well as social (street as a place for festivals and events). Introducing elements of traffic calming (including greenery) could significantly enhance this multifunctionality. The presented European and MENA examples differ by environmental and technical conditions, social and cultural compounds. For this reason, one should consider the possibility of introducing good European practices into the road space, e.g. in Lebanon and Jordan. Not all of the proposed standards can be implemented or directly copied. However, the general principles of traffic calming are common and applicable. In countries such as Poland and Slovakia, it would also be necessary to intensify the measures to improve road safety, and to implement recommendations for good road space planning based, for example, on Dutch and German examples. The proposed solutions should first of all take into account the specificity of the place.

Therefore, the general recommendations regarding the planning of roadside space and the introduction of plants to the traffic calming measures are formulated: 
1. Traffic calming gives more space to unprotected road users - pedestrians and cyclists. The implementation of speed-reducing elements in a given area increases the attractiveness of the surrounding. By giving a safe pedestrian space, the quality of life is improved.

2. One of the recommended ways of traffic calming is the introduction of the tempo 30 zone (especially in Lebanon and Jordan but also in Poland and Slovakia). It is a separate area in a city where the maximum speed is 30 $\mathrm{km} / \mathrm{h}$. At the entrance to the zone should be used visual gates, such as raising the intersection, changing the texture of the surface, greenery.

3. Another recommended element is the optical reduction of the width of lanes. In some countries, we often find two-way roadways or two-three-lane roadways in the city center. And the empty, wide roadway psychologically encourages faster driving. By moving at the prescribed speed one can get the impression that driving is too slow compared to the "possibilities" of the road. When the lane is narrow, it requires more attention from the driver, because there is an element of risk.

4. It is also worth to consider elevated pedestrian crossings, which in combination with the narrowing of the road give more space for pedestrians and increase their visibility. Narrow up the road lanes together with the use of other elements of traffic calming, for example by placing trees in the middle of the road. Such solutions are used, among others, at the entrances to the village, to suggest the need to reduce the speed, entering the built-up area.

5. Last but not least tool for traffic calming is shared space, i.e. shared space - an area where there are no places for individual road users: pedestrians, cyclists, public transport, car drivers. Everyone operates on the same level and on the same rights, taking into account the radical limitation of the speed of motor vehicles.

6. With regard to the developed space in the transportation zones in selected regions, the specificity of the place should first be emphasized. It should maintain the unique character of the social space at the roadside (especially at the entrances to the town) of a symbolic, religious or cultural nature. However, it is worth to think about design method, limiting the number of elements, e.g., at the roundabout, because they can distract drivers.

7. The positive aspect of introducing vegetation as a material for traffic calming zones should be underlined. Vegetation often has a prestigious, ornamental character, and ultimately can affect the traffic calming. In Lebanon and Jordan, spaces at entrances and central points of cities are an example of green forms, which are relatively rare in another public space (due to local natural factors). When selecting species attention should be paid to the use of native species, as well as access to water. Only then some of European standards and models can be adopted in the development of roundabouts, narrowings, and islands on the road. 


\section{References}

Al-Masaeid H.R. (1999), Capacity and Performance of Roundabouts, "Canadian Journal of Civil Engineering", 26.

Bain L., Gray B., Rodgers D. (2012), Living Streets: Strategies for Crafting Public Space, John Wiley \& Sons, New York.

Bezák B. (2005), Technical Conditions - Design Principles of Traffic Calming Elements on Roads in Villages and Towns, with Efficacy from $15^{\text {th }}$ of December 2005, Slovak Technical University, Bratislava.

Brazinova A., Majdan M. (2016), Road Traffic Mortality in the Slovak Republic in 1996-2014, “Traffic Injury Prevention”, 17 (7).

Budzyński M., Gaca S., Kieć M. (2017), Speed Management on Local Government Managed Roads - Research, Recommendations and Guidelines, GAMBIT 2016, MATEC Web of Conferences 122, 03001, https://www.researchgate.net/publication/319049480_Speed management_on_local_government_managed_roads_-_research_recommendations _ and_guidelines [accessed: 9 November 2018].

Cebon D. (1993), Interaction between Heavy Vehicles and Roads. No. 930001. SAE Technical Paper No. 930001.

Cervero R., Guerra E., Al S. (2017), Beyond Mobility: Planning Cities for People and Places, "Island Press", 296.

City of Toronto, Transportation Services Division (2016), Traffic Calming Guide For Toronto, https://www.toronto.ca/legdocs/mmis/2016/pw/bgrd/backgroundfile-94207.pdf[accessed: 15 November 2018].

De balans opgemaakt Duurzaam Veilig 1998-2007 Stichting Wetenschappelijk Onderzoek Verkeersveiligheid SWOV (2009), Stichting Wetenschappelijk Onderzoek Verkeersveiligheid SWOV, Leidschendam.

Department of Transport, Traffic Calming, Local Transport Note 1/07, Department of Transport, Department for Regional Development (Northern Ireland), March (2007), https:// assets.publishing.service.gov.uk/government/uploads/system/uploads/attachment_ata/ file/329454/ltn-1-07_Traffic-calming.pdf [accessed: 15 November 2018].

Fluit N. van der, Cuperus R., Canters K.J. (1990), Mitigerende en compenserende maatregelen aan het hoofdwegennet voor het bevorderen van natuurwaarden (mitigating and compensating measures to the major road network for helping nature values), CML Mededelingen 65, Centrum voor Milieukunde, Rijksuni-versiteit Leiden.

FRIL (2005), Teaching Materials for National Road Safety Council, Foundation for Civil Engineering Development in Gdansk. Ministry of Infrastructure, Warsaw (Poland).

Galante F., Mauriello F., Montella A., Pernetti M., Aria M., D’Ambrosio A. (2010), Traffic Calming along Rural Highways Crossing Small Urban Communities: Driving Simulator Experiment, "Accident Analysis \& Prevention", 6 (42).

Hamilton-Baillie B. (2008), Shared Space: Reconciling People, Places and Traffic, "Built Environment", 2 (34).

Jaarsma C.F., Willems G.P.A. (2002), Reducing Habitat Fragmentation by Minor Rural Roads through Traffic Calming, "Landscape and Urban Planning", 2-4 (58). 
Jamrozik K., Nowak P., Bohatkiewicz J. (2009), Kompleksowe wdrażanie uspokajania ruchu na przykładzie projektu ,Miasteczko Holenderskie” w Puławach oraz prezentacja wybranych rozwiąań technicznych, "Zeszyty Naukowo-Techniczne Stowarzyszenia Inżynierów i Techników Komunikacji w Krakowie”, 89 (146).

Jaszczak A. (2008), Droga krajobrazowa jako produkt turystyczny, "Nauka Przyroda Technologie", 2, 4 (42).

Kristiánová K., Marcinková D. (2015), Cestné komunikácie ako verejný priestor a cestná zelen̆. Road Communications and Roadside Greenery [in:] Territorial Perspectives III: Public Spaces and Places, ČVUT, Prague.

Madbouly M. (2009), Revisiting Urban Planning in the Middle East North Africa Region, https://unhabitat.org/wp-content/uploads/2010/07/GRHS.2009.Regional.MENA_.pdf [accessed: 16 April 2018].

Reid E. (1999), Traffic Calming. State of the Practice, Institute of Transportation Engineers, Federal Highway Administration, Washington.

Road Safety in Traffic-Calming Zones (2015), German Insurance Association, German Accident Research, Berlin.

Samaha S. (2015), Landscape Design as Catalyst for Road Safety [in:] J. Makhzoumi (ed.), Unfolding Middle Eastern Landscapes: Changing Forms, Evolving Tool, Transforming Meanings, FLA LELA Conference Proceedings, Beirut 2016.

Sipes J.L., Sipes M.L. (2013), Creating Green Roadways. Integrating Cultural, Natural and Visual Resources into Transportation, Island Press, Washington.

Taylor D., Tight M. (1996), Feet First: Public Attitudes and Consultation in Traffic Calming Schemes. A Report for Transport 2000 Trust, Transport 2000 Trust.

Traffic Department (2016), The Statistics Of Traffic Accidents, https://www.psd.gov.jo [accessed: 17 April 2018].

Wallen M.A. (1961), Landscaped Structures for Traffic Control, “Traffic Engineering”, 4 (31).

Webster D.C., Tilly A., Buttress S. (2005), Pilot Home Zone Schemes: Evaluation of Cavell Way, Sittingbourne, TRL Raport No. 50.

Woźny A. (2015), Wpływ warunków siedliskowych na stan zieleni przyulicznej, "Infrastruktura i Ekologia Terenów Wiejskich", 1 (3). 